\title{
Maria Kubacka
}

Politechnika Rzeszowska

e-mail: m.kubacka@prz.edu.pl

\section{PROBLEMATYKA WYKORZYSTANIA EKONOMICZNEJ WARTOŚCI DODANEJ JAKO MIERNIKA WARTOŚCI PRZEDSIĘBIORSTWA}

\section{ISSUE OF USE OF ECONOMIC VALUE ADDED} AS A MEASURE OF ENTERPRISE VALUE

DOI: $10.15611 /$ pn.2018.513.22

JEL Classification: M40

\begin{abstract}
Streszczenie: W świetle współczesnych wymagań stawianych przedsiębiorstwom niewystarczające stają się narzędzia oceny ich działalności oparte na relacjach pomiędzy zyskiem, wartością kapitałów lub aktywów. Wynikiem takiego stanu rzeczy stało się zainteresowanie koncepcją zarządzania wartością przedsiębiorstwa, ukierunkowaną na generowanie (maksymalizowanie) wartości dla właścicieli. Celem artykułu jest wskazanie problematyki wykorzystania metody ekonomicznej wartości dodanej jako miernika służącego ocenie wartości przedsiębiorstwa. Realizacja tak postawionego celu wiązała się z wykorzystaniem krytycznego przeglądu literatury jako podstawowej metody badawczej. Omówiono istotę i pomiar wartości przedsiębiorstwa oraz zaprezentowano metodologię ustalania ekonomicznej wartości dodanej. Podjęte badania wskazują z pozoru nieskomplikowany sposób ustalenia miernika. Pojawiają się jednak pewne dylematy w zakresie m.in. wyznaczania i możliwości wpływania na jego elementy składowe oraz stosowane korekty.
\end{abstract}

Słowa kluczowe: zarządzanie wartością przedsiębiorstwa, ekonomiczna wartość dodana, mierniki wartości.

Summary: In the light of modern requirements for enterprises, the tools for assessing their operations based on the relationship between profit, equity or assets are insufficient. The result of this state of affairs was the interest in the concept of enterprise value management, aimed at generating (maximizing) values for owners. The purpose of this article is to indicate the issue of the use of the method of economic added value as a measure to assess the value of an enterprise. The implementation of this objective was associated with using the critical review of literature as the primary test method. The essence and measurement of the company's value was discussed and the methodology for determining the economic value added was presented. The research undertaken indicates a seemingly uncomplicated way of establishing the meter. However, there are some dilemmas in terms of, among other things, determining and the possibility of influencing its components and applied adjustments.

Keywords: value based management, economic value added, value measures. 


\section{Wstęp}

Zarządzanie ukierunkowane na tworzenie wartości stanowi kompleksowe podejście do zarządzania zdeterminowanego osiągnięciem nadrzędnego celu w postaci wzrostu wartości przedsiębiorstwa [Hawawini, Viallet 2007, s. 567].

Współcześnie coraz bardziej istotne staje się zarządzanie wartością przedsiębiorstwa. Menedżerowie przedsiębiorstw ukierunkowują się na tworzenie wartości dla właścicieli, akcjonariuszy. Wpływa to na zainteresowanie metodami zarządzania wartością przedsiębiorstw, z których wynika odpowiednia ocena skuteczności i efektywności zarząadzania.

Informacje uzyskiwane z systemu księgowego są niewystarczające. Konieczne staje się wykorzystanie metod pomiaru prezentujących wpływ podejmowanych działań na wartość przedsiębiorstwa.

Celem artykułu jest przedstawienie problematyki wykorzystania metody ekonomicznej wartości dodanej (EVA - Economic Value Added) jako miernika pomiaru wartości przedsiębiorstwa. Realizacja tak postawionego celu wiązała się z wykorzystaniem krytycznego przeglądu literatury jako podstawowej metody badawczej.

\section{Istota i pomiar wartości przedsiębiorstwa}

W literaturze polskiej i zagranicznej można znaleźć odniesienia do definicji zarządzania wartością przedsiębiorstwa. Przy jej określaniu zwraca się szczególną uwagę na cele, jakie ma do zrealizowania, oraz obszary jej wykorzystania.

Pomiar wartości znajduje się w centrum zainteresowania koncepcji zarządzania przez wartość (VBM - Value Based Management) [Nowicki 2014, s. 589]. Jej definicję najogólniej oddaje stwierdzenie, iż jest to „koncepcja kierowania przedsiębiorstwem zakładająca skupienie działań i procesów zarządczych na maksymalizowaniu jego wartości z punktu widzenia interesów właścicieli i zaangażowanych przez nich kapitałów. Zakłada ona sterowanie działalnością operacyjną i inwestycyjną przedsiębiorstwa w celu osiągnięcia podstawowego celu istnienia - podnoszenia wartości” [Szczepankowski 2012, s. 20].

Wartość przedsiębiorstwa utożsamiana jest ze zdolnością do pomnażania zainwestowanego w nie kapitału [Kaczmarek 2014, s. 6; Jaki 2013, s. 132].

W celu oceny dokonanego pomnożenia, zwiększenia wartości konieczne jest porównanie osiągniętego wyniku z innymi realizowanymi czy też oczekiwanych stóp kreowania wartości. Konfrontacja uzyskanych rezultatów może przybierać formę benchmarku w odniesieniu do rynku, branży, konkurentów. Porównanie natomiast oczekiwanych stóp kreowania wartości polega na zdefiniowaniu nadmiarowego zwrotu (wartości) w zestawieniu z minimum zwrotu wymaganego przez właścicieli [McTaggart, Kontes, Mankins 1994, s. 69-84; Capron, Pistre 2002, s. 794; Rappaport 1986, s. 104]. 
Zarządzanie wartością przedsiębiorstwa definiowane jest również jako koncepcja, która właściwie oddaje cele działania przedsiębiorstwa oraz sprzyja integracji celów menedżerów i właścicieli [Jaki 2008, s. 142].

Problematyka ,wartości” przedstawiana jest niejednoznacznie i wieloaspektowo [Sojda 2013, s. 269; Miles 1984, s. 15]. Toteż klasyfikacje dotyczące metod szacowania wartości są zróżnicowane. Wyróżnia się metody majątkowe, dochodowe i rynkowe, a według innej klasyfikacji majątkowe, dochodowe i mieszane [Paździor 2015, s. 51-72].

Idea pomiaru wartości przedsiębiorstwa wynika głównie z przeświadczenia, że informacje pochodzące $z$ ewidencji księgowej oraz tworzone na tej podstawie miary (ROE, ROI, ROA) nie są wystarczającym źródłem do podejmowania decyzji [Karmańska 2009, s. 102]. Podyktowane jest to stwierdzeniem, że spółka jest zyskowna nie w momencie, gdy pokryje koszty produkcji, a dopiero w sytuacji, w której zapewnia swoim właścicielom stopę zwrotu z zainwestowanego kapitału, przynajmniej na poziomie alternatywnego kosztu kapitału własnego [Nowicki 2017, s. 345]. Co więcej, w literaturze prezentowany jest szereg zarzutów stawianych wobec mierników księgowych [zob. Nita 2007, s. 107-108].

W związku z występującymi ograniczeniami, jakie niosą ze sobą wskaźniki księgowe, a w szczególności nieuwzględnianie kosztu kapitału własnego, który w głównej mierze determinuje osiągnięcie zysku [Lehn, Makhija 1996, s. 35], zaistniała potrzeba skonstruowania mierników, które odpowiednio wyceniałyby wartość przedsiębiorstwa.

Wśród kluczowych mierników charakteryzujących zdolność przedsiębiorstwa do kreowania wartości wymienia się [Karmańska 2009, s. 103]:

- ekonomiczną wartość dodaną - EVA (Economic Value Added),

- rynkową wartość dodaną - MVA (Market Value Added),

- wartość dodaną dla akcjonariuszy - SVA (Shareholder Value Added),

- ekonomiczną wartość dodaną dla właścicieli - SEVA (Shareholder Economic Value Added),

- $\quad$ stopę zwrotu dla akcjonariuszy - CFROI (Cash Flow Return on Investment),

- całkowity zwrot dla akcjonariuszy - TSR (Total Shareholder Return),

- całkowity zwrot z przedsiębiorstwa - TBR (Total Business Return).

Wymienione mierniki wykorzystywane są przez szerokie grono interesariuszy organizacji oraz jej menedżerów.

\section{Metoda ustalania ekonomicznej wartości dodanej}

Koncepcja ekonomicznej wartości dodanej została zaprezentowana przez J. Sterna i G.B. Stewarta III pod koniec lat 80. XX w. [Grant 2003, s. 1-3]. Według prekursorów $\mathrm{EVA}^{1}$ jest metodą, która pozwala mierzyć i oceniać proces kreowania wartości

${ }^{1}$ EVA jest znakiem towarowym nowojorskiej firmy konsultingowej Stern Stewart \& Co. 
w sposób kompleksowy. Całościowe podejście do pomiaru wartości przedsiębiorstwa wyraża się w uwzględnieniu w prezentowanej metodzie kosztu pozyskania składników majątku, w tym również kosztu kapitału własnego, pomijanego w miernikach księgowych [Jaki 2008, s. 136].

Metodologia ekonomicznej wartości dodanej opiera się na modyfikacji koncepcji dochodu rezydualnego, sformułowanego jeszcze w latach 90. XX w. przez Marshalla, zgodnie z którą przedsiębiorstwo generuje zysk dopiero w momencie, gdy pokryje koszt kapitału własnego i obcego [Wypych 2014, s. 463].

Formuła EVA przedstawia się następująco [Mikołajek-Gocejna 2007, s. 147; Cwynar, Cwynar 2007 s. 32]:

$$
E V A_{t}=E B I T_{t}(1-T)-W A C C_{t} \times I C_{t-1}=N O P A T_{t}-W A C C_{t} \times I C_{t-1},
$$

przy czym [Dyduch i in. 2013, s. 316]:

$$
W A C C_{t}=\sum_{t-1}^{n} w_{i} \times k_{i}
$$

przy uwzględnieniu efektu tarczy podatkowej [Stewart 1991, s. 137]:

$$
W A C C_{t}=w_{a} \times k_{a}(1-T)+w_{b} \times k_{b},
$$

gdzie: $E V A_{t} \quad-$ ekonomiczna wartość dodana na okres $t$;

$T \quad$ - stopa podatku dochodowego;

$E B I T_{t}$ - zysk operacyjny przed opodatkowaniem na okres $t$;

NOPAT $T_{t}$ zysk operacyjny po opodatkowaniu na okres $t$;

$W A C C_{t}$ - średni ważony koszt kapitału w okresie $t$;

$I C_{t-1} \quad$ zainwestowany kapitał występujący na koniec okresu $(t-1)$;

$W A C C_{t} \times I C_{t-1}-$ wartościowe wyrażenie całkowitego kosztu kapitału;

$w_{i} \quad$ - stopa kosztu kapitału pozyskanego z $i$-tego źródła;

$k_{i} \quad-$ udział kapitału pozyskanego z $i$-tego źródła w kapitale przedsiębiorstwa;

$w_{a} \quad$ - udział kapitału obcego w kapitale przedsiębiorstwa;

$w_{b} \quad$ - udział kapitału własnego w kapitale przedsiębiorstwa;

$k_{a} \quad$ - stopa kosztu kapitału obcego;

$k_{b} \quad$ - stopa kosztu kapitału własnego.

Z formuły EVA wynika, że ekonomiczna wartość dodana jest różnicą między wynikiem po opodatkowaniu (netto) a iloczynem oczekiwanych przez dawców kapitału zysków (w postaci wyrażonego wartościowo kosztu kapitału własnego i obcego).

W celu uzyskania wartości EVA możliwe jest również pomniejszenie osiąganej przez inwestorów stopy zwrotu z zainwestowanego kapitału o całkowity koszt kapitału, kolejno pomnożonego przez wartość zainwestowanego kapitału [Karmańska 2009, s. 105; Jagiełło 2004, s. 59]:

$$
E V A_{t}=R O I C_{t} \times I C_{t-1}-W A C C_{t} \times I C_{t-1}=\left(R O I C_{t}-W A C C_{t}\right) \times I C_{t-1},
$$


gdzie:

$$
R O I C_{t}=\frac{E B I T \times(1-T)}{I C_{t-1}}=N O P A T_{t} / I C_{t-1},
$$

$R O I C_{t}$ - stopa zwrotu z zainwestowanego kapitału w okresie $t$.

Biorąc pod uwagę powyższy wzór, należy zauważyć, że ekonomiczna wartość dodana przedstawia wartość do dyspozycji inwestorów po pomniejszeniu jej o wszelkie koszty. W sytuacji gdy $R O I C_{t}>W A C C_{t}$, wówczas $E V A_{t}>0$, co oznacza strefę ekonomicznych zysków, czyli wygenerowane środki są większe niż koszt kapitału zaangażowanego, co przekłada się na dodatkową wartość dla przedsiębiorstwa. Natomiast gdy $R_{O I C_{t}}<W A C C_{t}$, oznacza, że $E V A_{t}<0$, wygenerowane w przedsiębiorstwie środki są niższe od kosztu zaangażowanego kapitału. Równość pomiędzy $R O I C_{t}$ i $W_{A C C_{t}}$ oznacza, że wartość dodana wynosi zero [Mikołajek-Gocejna 2007, s. 148].

W sytuacji gdy celem przedsiębiorstwa jest zwiększanie jego wartości dla akcjonariuszy, wówczas istnieje konieczność zwiększania EVA. Można tego dokonać w następujący sposób [Mikołajek-Gocejna 2007, s. 149-150]:

- zwiększając ROIC przy określonym poziomie WACC, czego efektem będzie wzrost różnicy ekonomicznej, a tym samym EVA,

- inwestując kapitał w nowe przedsięwzięcia charakteryzujące się dodatnim NPV,

- zmniejszając WACC przez optymalizację jego struktury,

- długookresowo utrzymując nadwyżkową stopę zwrotu w odniesieniu do kapitału zaangażowanego w przedsiębiorstwie.

W celu obliczenia EVA konieczne jest określenie sposobu ustalenia kapitału zainwestowanego oraz zysku operacyjnego. Kapitał zainwestowany odzwierciedla całościową sumę środków pieniężnych ulokowanych w okresie działalności przedsiębiorstwa, bez względu na miejsce pochodzenia oraz cel, na jaki zostały zaangażowane [Stewart 1991, s. 86]. Kapitał zainwestowany w przedsiębiorstwie obejmuje zarówno kapitał własny, jak i kapitał obcy oprocentowany krótko- i długoterminowy.

Wartość kapitału zainwestowanego, jak również zysk operacyjny można obliczyć jednym z wybranych podejść: finansowym lub operacyjnym [zob. Buk 2006, s. 235-236].

Szczególnie istotnym elementem metodologii EVA jest ustalenie średnioważonego kosztu kapitału (WACC), który w dużym stopniu narażony jest na subiektywizm ze strony osoby go obliczającej.

Jednym z możliwych wariantów ustalenia kosztu kapitału obcego jest ustalenie udziału zapłaconych odsetek, prowizji i innych kosztów związanych z kapitałem obcym w stosunku do wielkości tego kapitału. Konieczne jest w tym względzie ustalenie kosztu średnioważonego. Inny sposób ustalenia kosztu kapitału obcego to obliczenie go na podstawie obowiązujących stawek oprocentowania [Karmańska 2009, s. 106]. 
Wycenę kosztu kapitału własnego przeprowadza się z wykorzystaniem następujących modeli [Michalski 2010, s. 121-127]:

- model wyceny aktywów kapitałowych CAMP,

- model stałego wzrostu dywidendy,

- model stopy zwrotu z obligacji plus premia za ryzyko.

Koncepcja EVA różni się od zysku rezydualnego o szereg korekt [Dodd, Chen 1996, s. 26-28 za: Shil 2009, s. 169-170], niezbędnych w celu przybliżenia informacji z ewidencji księgowej do wartości przepływów pieniężnych. Stern i Stewart III proponują aż 164 korekty, zarówno zysku operacyjnego, jak i kapitału zainwestowanego. Rzeczywista ich liczba uzależniona jest jednak od rodzaju działalności przedsiębiorstwa oraz stosowanych przez nie rozwiązań prawnych. Jeżeli przedsiębiorstwo nie wykonuje żadnych korekt, wówczas otrzymuje zysk rezydualny, a nie ekonomiczną wartość dodaną [Kąkol 2003, s. 42-44; Nita (red.) 2007, s. 166-168].

Należy zauważyć, iż pomimo dokonania licznych korekt księgowych zarówno zysku operacyjnego, jak i zainwestowanego kapitału, EVA nie musi odzwierciedlać rzeczywistego przyrostu bogactwa dla właścicieli, ponieważ inwestorzy oczekują określonej, minimalnej stopy zwrotu na podstawie wartości rynkowej [Nowak (red.) 2013, s. 239-240].

\section{Dylematy stosowania ekonomicznej wartości dodanej}

Wykorzystanie koncepcji ekonomicznej wartości dodanej do wyceny wartości przedsiębiorstwa wydaje się bezdyskusyjne. Autorzy EVA przekonują, że jej stosowanie stanowi właściwe zabezpieczenie przed utratą wartości przedsiębiorstwa. Wskazać można szereg zalet, jakie przypisywane są ekonomicznej wartości dodanej [Nowicki 2010, s. 200-209; Karmańska 2009, s. 111-112; Świderska (red.) 2002, rozdz. 12, s. 98-100]:

- uwzględnia całkowity koszt kapitału (własnego i obcego),

- jest miernikiem wewnętrznym,

- informuje o kreowaniu czy pomniejszaniu wartości dla właścicieli,

- sprzyja decentralizacji zarządzania i może być wykorzystywana na różnych szczeblach struktury organizacyjnej,

- może mieć zastosowanie w systemach wczesnego ostrzegania,

- wykonywane korekty w celu ustalenia wartości EVA zbliżają ten wskaźnik do salda przepływów pieniężnych,

- jest zgodna z metodą NPV,

- umożliwia adekwatne porównanie przedsiębiorstw niezależnie od struktury kapitału,

- uświadamia, że kapitał własny nie jest darmowy.

Przedstawione zalety są jednak przedmiotem dyskusji. W literaturze przedmiotu można znaleźć przykłady potencjalnych konfliktów pomiędzy EVA a wartością przedsiębiorstwa [Dudycz 2005]: 
1. Uzależnienie wartości EVA od zainwestowanego kapitału IC, co może powodować dążenie zarządu do zmniejszania wartości zainwestowanego kapitału poprzez następujące działania:

- przeprowadzenie restrukturyzacji, która nie wpłynie na wzrost przepływów operacyjnych, a koszty z nią związane zmniejszą IC,

- stosowanie leasingu operacyjnego, którego celem będzie poniesienie mniejszych wartości płatności leasingowych niż ewentualny zakup aktywów w sposób tradycyjny,

- wykorzystanie EVA do oceny efektywności działów przedsiębiorstwa, które uzależnione jest od stopnia przypisania kapitału, co może skutkować tym, że działy, które będą miały przypisany mniejszy kapitał, uzyskają wyższy EVA w porównaniu z działami, którym przypisze się go więcej.

2. Manipulowanie przyszłym wzrostem, zwiększając aktualną wartość EVA kosztem zmniejszania jej z przyszłych inwestycji.

3. Wpływanie na koszt kapitału, który jest uzależniony od ryzyka. Współczynnik ryzyka $\beta$ jest elementem najbardziej wrażliwym na subiektywne określenie [Karmańska 2009, s. 107-108]. Ponadto jest on ustalany na podstawie danych historycznych, przez co zarząd może podejmować decyzje bardziej ryzykowne, mające na celu zwiększenie przepływów operacyjnych, a w następstwie EVA w początkowym okresie, ponieważ współczynnik $\beta$ wzrośnie z opóźnieniem.

Nierzadko wskazywane są również wady ekonomicznej wartości dodanej, które stosunkowo komplikują rzetelne ustalenie i wykorzystanie wartości EVA [Karmańska 2009, s. 111-112; Świderska (red.) 2002, rozdz. 12, s. 98-100]:

- jest miernikiem krótkookresowym,

- problemy związane z ustaleniem kosztu kapitału własnego,

- występowanie wielu korekt,

- całkowite pomijanie przychodów z działalności finansowej (niekiedy zdarza się, że przedsiębiorstwa działalnością finansową rekompensują straty poniesione na działalności operacyjnej),

- wartość wskaźnika może wprowadzić w błąd w przedsiębiorstwach objętych restrukturyzacją.

Wymienione wady ekonomicznej wartości dodanej, w szczególności wynikające z problematycznych składowych koncepcji, sprawiają, że stosowanie EVA do wyceny wartości przedsiębiorstwa w literaturze oceniane jest niejednoznaczne.

Składowa w szczególności cechująca się dyskusyjnym charakterem to średnioważony koszt kapitału, a dokładnie ustalenie kosztu kapitału własnego.

Problematykę wykorzystania miernika ekonomicznej wartości dodanej szeroko opisuje Szymański [2014, s. 170-172]. Przywołując różne wyniki badań, ukazuje ich sprzeczność z funkcjonowaniem miernika, EVA jest bowiem miernikiem wykreowanej wartości dla właścicieli, więc odnosi się do przeszłości. Inwestorzy natomiast zainteresowani są przyszłymi wynikami przedsiębiorstwa. 


\section{Zakończenie}

Wiarygodny i miarodajny system pomiaru i oceny dokonań przedsiębiorstwa uwzględniający całościowe podejście do podmiotu gospodarczego to niewątpliwie warunek powodzenia polityki przedsiębiorstwa.

Wartość przedsiębiorstwa, a w szczególności mierniki będące odzwierciedleniem jej wzrostu bądź spadku, stanowią istotny element zainteresowania menedżerów przedsiębiorstw. Zaprezentowana metoda ekonomicznej wartości dodanej jest jednym z mierników, jak przedstawiono w artykule, nieco dyskusyjnym w zastosowaniu i wykorzystaniu do oceny wartości podmiotu gospodarczego. Pomimo jednak wielu problematycznych kwestii, takich jak chociażby sposób ustalenia kosztu kapitału własnego, konieczność wykonywania licznych korekt, a w końcu bazowanie na danych historycznych, EVA pozostaje metodą coraz częściej wykorzystywaną do ustalania wykreowanej wartości przedsiębiorstwa.

\section{Literatura}

Buk H., 2006, Nowoczesne zarządzanie finansami. Planowanie i kontrola, C.H. Beck, Warszawa.

Capron L., Pistre N., 2002, When do acquirers earn abnormal returns? "'Strategic Management Journal", $\mathrm{nr} 23$.

Cwynar A., Cwynar W., 2007, Kreowanie wartości spótki poprzez dlugoterminowe decyzje finansowe, Polska Akademia Rachunkowości oraz Wydawnictwo Wyższej Szkoły Informatyki i Zarządzania z siedzibą w Rzeszowie, Warszawa-Rzeszów.

Dodd J.L., Chen S., 1996, EVA: A new Panacea?, "Business and Economic Review”, July-September.

Dudycz T., 2005, Zarządzanie wartościa przedsiębiorstwa, PWE, Warszawa 2005.

Dyduch A., Sierpińska M., Wilimowska Z., 2013, Finanse i rachunkowość, PWE, Warszawa.

Grant J.L., 2003, Foundations of Economic Value Added, Second Edition, J. Wiley\&Sons, New Jersey. Hawawini G., Viallet C., 2007, Finanse menedżerskie, PWE, Warszawa.

Jagiełło K., 2004, Ekonomiczna wartość dodana EVA w systemie mierników finansowych wykorzystywanych w zrównoważonej karcie wyników, Zeszyty Naukowe MWSE w Tarnowie, z. 6, zn.mwse. edu.pl (dostęp: 13.03.2018).

Jaki A., 2008, Wycena i ksztattowanie wartości przedsiębiorstwa, Wolters Kluwer, Kraków.

Jaki A., 2013, Pomiar i ocena efektywności kreowania wartości w przedsiębiorstwie, Zeszyty Naukowe Uniwersytetu Szczecińskiego nr 770, Finanse, Rynki, Ubezpieczenia nr 59, www.wneiz.pl (dostęp: 10.03.2018).

Jevons W.S., 1871, The Theory of Political Economy, London, www.econlib.org (dostęp: 12.03.2018).

Kaczmarek J., 2014, Kreowanie wartości dla akcjonariuszy w spótkach giełdowych sektora nieruchomości, [w:] Świat Nieruchomości, "World of Real Estate Journal”, nr 88/2014, swiatnieruchomosci.krakow.pl (dostęp: 10.03.2018).

Karmańska A., 2009, Wartość ekonomiczna w systemie informacyjnym rachunkowości finansowej, Wydawnictwo Difin, Warszawa.

Kąkol W., 2003, Wykorzystanie modelu EVA do szacowania wartości przedsiębiorstwa, „Controlling i Rachunkowość Zarządcza”, nr 1.

Lehn K., Makhija A., 1996, EVA \& MVA as Performance Measures and Signals for Strategic Change, "Strategy and Leadership", May/June. 
McTaggart J.M., Kontes P.W., Mankins M.C., 1994, Value Imperative: Managing for Superior Shareholder Returns, The Free Press, New York.

Michalski G., 2010, Wprowadzenie do zarządzania finansami przedsiębiorstw, Wydawnictwo C.H. Beck, Warszawa.

Mikołajek-Gocejna M., 2007, Ksztattowanie wartości dla akcjonariuszy na podstawie koncepcji Value Based Management, [w:] Przedsiębiorstwo. Wartość. Zarzadzanie, red. C. Suszyński, PWE, Warszawa.

Miles R.C., 1984, Basic Business Appraisal, John Wiley \& Sons, New York.

Nita B., 2007, Metody wyceny i ksztaltowania wartości przedsiębiorstwa, PWE, Warszawa.

Nita B. (red.), 2007, Budżetowanie w przedsiębiorstwie. Organizacja, procedury, zastosowanie, Wolters Kluwer Business, Kraków.

Nowak E. (red.), 2013, Controlling dla menedżerów, Wydawnictwo CeDeWu, Warszawa.

Nowicki D., 2017, Dyskusyjne problemy ustalania i wykorzystania ekonomicznej wartości dodanej, Zeszyty Naukowe Uniwersytetu Szczecińskiego, nr 88, cz. 1, Finanse, Rynki, Ubezpieczenia, nr 4, wnus.edu.pl (dostęp: 10.03.2018).

Nowicki J., 2010, Zarządzanie wartościa przedsiębiorstwa w sytuacji braku rozdziału funkcji zarzączych od właścicielskich, Uniwersytet Ekonomiczny w Poznaniu, Poznań.

Nowicki J., 2014, Systematyka metod pomiaru wartości w ramach zarzadzania wartościa przedsiębiorstwa, Zeszyty Naukowe Uniwersytetu Szczecińskiego nr 804, Finanse, Rynki, Ubezpieczenia, nr 67, www.wneiz.pl (dostęp: 10.03.2018).

Paździor A., 2015, Zarządzanie wartościa wspótczesnego przedsiębiorstwa, Wydawnictwo Politechniki Lubelskiej, Lublin, bc.pollub.pl (dostęp: 12.03.2018).

Rappaport A., 1986, Creating Shareholder Value. A Guide for Managers and Investors, The Free Press, New York.

Shil N.C., 2009, Performance Measures: An Application of Economic Value Added, "International Journal of Business and Management", Vol. 4, No 3, www.ccsenet.org (dostęp: 13.03.2018).

Sojda A., 2013, Wartości wybranych przedsiębiorstw górniczych przy zastosowaniu EVA, Zeszyty Naukowe Uniwersytetu Szczecińskiego nr 786, Finanse, Rynki, Ubezpieczenia nr 64/1, www.wneiz. pl (dostęp: 10.03.2018).

Stewart G.B., 1991, The Quest for Value. A Guide for Senior Managers, Harper Business, New York.

Szczepankowski P., 2012, Wycena i zarządzanie wartościa przedsiębiorstwa, Wydawnictwo Naukowe PWN, Warszawa.

Szymański P., 2014, Ewolucja koncepcji zarządzania wartościa przedsiębiorstwa-przeglad literatury, Prace Naukowe Uniwersytetu Ekonomicznego we Wrocławiu, nr 340.

Świderska G.K. (red.), 2002, Rachunkowość zarządcza i rachunek kosztów, t. II, Difin, Warszawa.

Wypych M., 2014, Ekonomiczna wartość dodana w małych spółkach giełdowych, Ekonomiczne Problemy Usług, nr 111, Zeszyty Naukowe Uniwersytetu Szczecińskiego nr 799, www.wzieu.pl (dostęp: 13.03.2018). 